\title{
Low-Dose $17 \beta$-Estradiol Supplemented with Andrographis Paniculata Improved Glucose and Lipid Homeostasis in a Type-2 Diabesity Mice Model
}

\author{
Ikechukwu Sonne Mbagwu ${ }^{1}$, Obiora Celestine $\mathrm{Ugwu}^{2}$, Uchechukwu Harrison Orji ${ }^{1}$, Raymond Ogbonna Offiah ${ }^{3}$, Daniel \\ Ikechukwu Oraekei ${ }^{1}$ and Daniel lotanna Ajaghaku ${ }^{2 *}$ \\ ${ }^{1}$ Department of Pharmacology and Toxicology, Faculty of Pharmaceutical Sciences, Nnamdi Azikiwe University, Awka, Anambra State, Nigeria \\ ${ }^{2}$ Department of Pharmacology, Faculty of Pharmaceutical Sciences, Enugu State University of Science and Technology, Enugu State, Nigeria \\ ${ }^{3}$ Department of Pharmacology and Therapeutics, Faculty of Basic Medical Sciences, College of Medicine, Enugu State University of Science and Technolo- \\ gy, Enugu State, Nigeria
}

${ }^{\star}$ Corresponding author: Ajaghaku Daniel Lotanna, Department of Pharmacology, Faculty of Pharmaceutical Sciences, Enugu State University of Science and Technology, Enugu State, Nigeria, Tel: +2347035601780; E-mail: daniel.ajaghaku@esut.edu.ng

Received: December 02, 2020; Accepted: December 04, 2020; Published: December 16, 2020

\begin{abstract}
Estrogens play an important role in metabolic homeostasis. However, its risk of uncogenecity and cardiovascular adverse effects underscores its therapeutic benefits. This study investigated the metabolic effect of low dose estrogen supplemented with Andrographis paniculata on type-2 diabesity mice model. The experimental animals maintained on high fat diet were induced diabetes with streptozotocin (100 mg/kg) after intraperitoneal injection of $50 \mathrm{mg} / \mathrm{kg}$ nicotinamide. Low dose estrogen $(0.02 \mathrm{mg} / \mathrm{kg})$ was administered alone as well as in combination with 50,150 and $500 \mathrm{mg} / \mathrm{kg}$ of the ethanol extract of $A$. paniculata. These doses of the extract, vehicle $(5 \mathrm{ml} / \mathrm{kg}$ distilled water) and two reference standards-pioglitazone (30 mg/kg) and metformine (100 $\mathrm{mg} / \mathrm{kg})$ were used as controls. Oral glucose tolerant test was used to determine the effect of treatment on pancreatic $\beta$-cell function and insulin sensitivity following oral glucose load of $2 \mathrm{~g} / \mathrm{kg}$. Lipid profile tests and blood glucose measurements were used to evaluate effect of treatment on lipid homeostasis and chronic diabetes respectively. Combination of low dose estradiol with 150 and $500 \mathrm{mg} / \mathrm{kg}$ of the extract showed significant $(\mathrm{P}<0.05)$ reduction in blood glucose when compared to their individual monotherapeutic effects. Co-administration of the extract with estradiol at all doses of the extract produced significant $(\mathrm{P}<0.05)$ improvement in oral glucose tolerance as depicted by smaller AUC when compared to either the extract or estradiol alone. Low dose estradiol was unable to significantly improve diabesity associated lipid profile abnormalities. However, combination of both low doses of the extract ( $50 \mathrm{mg} / \mathrm{kg}$ ) and estradiol showed significant $(\mathrm{P}<0.05)$ reduction in serum TG and LDL-cholesterol as well as significant $(\mathrm{P}<0.05)$ increase in $\mathrm{HDL}$ compared to vehicle control group. These findings established that augmentation of low-dose estrogen with A. paniculata resulted in the improvement of glucose and lipid homeostasis in a type-2 diabesity mice model compared to their individual effects. The low-dose estrogen augmentation is expected to reduce the side effects of estrogen monotherapy while at the same time exploiting its metabolic potentials in glucose and lipid homeostasis.
\end{abstract}

Keywords: Estrogen; Metabolism; Angrographis paniculata; Diabesity

\section{Background}

Diabesity is a term describing diabetes in the context of obesity and sometimes referred to as obesity-dependent diabetes [1]. It is the continuum of progressive abnormal biology, which ranges from mild insulin resistance to full-blown type-2 diabetes [2]. Obesity-dependent diabetes has been recognized as a major public health challenge that is evolving to become an epidemic [3]. According to the report by Zambard et al. [4], diabesity and cardiovascular disease share many common risk factors including central obesity, hyperinsulinaemia, hyperglycaemia, elevated blood pressure and dyslipidaemia.

Beyond the well-recognised role of estrogen in the reproductive system, estrogens are important participants in metabolic regulation [5]. A strong correlation between estrogen deficiency and metabolic dysfunction has also been established [6]. This is consistent with studies demonstrating accelerated development of insulin resistance and type- 2 diabetes in postmenopausal women with reduced estrogen production [7]. Estrogen therapy due to its risk of oncogenecity underscores its therapeutic benefits in the maintenance of glucose and lipid homeostasis [8]. This potential risk factor can be averted by maintaining a low-dose estrogen therapy with possible augmentation of its therapeutic benefits by combining it with other bioactive compounds. This approach may provide superior benefits in glucose and lipid metabolism while at the same time keeping the risk of estrogen therapy in check.

The plant Andrographis paniculata (Family Acanthaceae) is one of the most popular medicinal plants used traditionally for the treatment of array of diseases including diabetes [9]. In more recent studies, compounds isolated from the alcoholic extract of the plant showed great potential to ameliorate diabetic nephropathy in MES-13 cells [10], while the ethanol extract significantly reduced blood glucose level in streptozotocin-induced hyperglycaemic rats [11]. Given the 
acclaimed blood glucose-lowering potentials of this plant, little or nothing has been documented about its effectiveness in diabesity presenting classical features of insulin resistance with consequent hyperglycaemia and hyperlipidaemia. Also the metabolic potential of low-dose $17 \beta$-estradiol (E2) suggested to reduce hepatic glucose output compromised in insulin resistance has not been fully exploited especially when combined with medicinal plants.

It is to this end that this study was set to investigate the contributions of low-dose $17 \beta$-estradiol (E2) augmentation on glucose and lipid homeostasis in male type-2 diabesity mice model treated with Andrographis paniculata.

\section{Materials and Methods}

\section{Plant Collection and Extraction}

The aerial part (leaves, seeds and stem) of $A$. paniculata was collected from the botanical garden of the Faculty of Pharmaceutical Sciences, Nnamdi Azikiwe University, Agulu. The plant was air dried at room temperature and pulverized into coarse powder. The powdered plant $(200 \mathrm{~g})$ was macerated in $2 \mathrm{~L}$ of ethanol for $72 \mathrm{~h}$ with intermittent shaking, filtered and concentrated using rotary evaporator at $50^{\circ} \mathrm{C}$. The resulting extract was stored at $0-4^{\circ} \mathrm{C}$ in the refrigerator till further use.

The percentage yield of the extract was calculated using the following formula:

$$
\text { Yield }(\%)=\frac{\text { Weight of the concentrated extract }(g)}{\text { weight of pulverized plant material }(g)}
$$

\section{Animals}

Swiss male Albino mice (25-30 g) were used for this study. The animals were obtained from the Animal House of the Department of Pharmacology/Toxicology, Nnamdi Azikiwe University, Awka. The animals were housed in standard laboratory condition. All animal studies were performed in accordance with $\mathrm{NIH}$ guidelines outlined in the Guide for the Care and Use of Laboratory Animals, as described in protocols reviewed and approved by the NnamdiAzikiwe University institutional Animal Care and Use Committee.

\section{Phytochemical Analysis}

The extract was subjected to qualitative determination of alkaloids, saponins, tannins, flavonoids, terpenoids and cardiac glycosides as well as quantitative determination of terpenoids, saponins, flanonoids and tannins were using standard procedures described by Odoh et al. [12].

\section{Acute Toxicity Study}

Acute toxicity analysis of the extracts was performed using Lorke's method as described by Agyigra et al. [13]. This first phase comprised of nine mice randomized into three groups of three mice each. Each group of animals was administered different doses (10, 100 and 1000 $\mathrm{mg} / \mathrm{kg}$ ) of the extracts. The mice were observed thereafter for 24 hours for signs of toxicity as well as mortality. The second phase was made up of four groups of one mouse each. Based on result of the first phase, they were administered 2000, 3000, 4000 and $5000 \mathrm{mg} / \mathrm{kg}$ of the extract respectively. Observations for toxicity and death were also done for $24 \mathrm{~h}$ post administration.

\section{Formulation of High Fat Feed}

High fat feed was formulated as described by Mbagwu et al. [14]. The diet was composed of $45 \%$ fat, $35 \%$ carbohydrate and $20 \%$ protein having total caloric energy value of $4057 \mathrm{Kcal} / \mathrm{kg}$ (Animal Care Feeds, Asaba, Nigeria) against normal mice diet that was found to composed of $10 \%$ fat , $70 \%$ carbohydrate and $20 \%$ crude protein with the same total caloric energy value of $4057 \mathrm{Kcal} / \mathrm{kg}$ (Animal Care feeds, Asaba, Nigeria).

\section{Effect of the Extract on High-Fat Diet Streptozotocin- Nicotinamide-induced Type 2 Diabetic Mice}

A total of 100 mice were used for this study. The animals were maintained on high fat diet with free access to water ad libitum for 4 weeks. Prior to induction of diabetes, $50 \mathrm{mg} / \mathrm{kg}$ of nicotinamide was injected intraperotoneally to provide partial protection of the beta cells from complete pancreatectomy. Thereafter, streptozotocin $(100 \mathrm{mg} / \mathrm{kg})$ was administered intraperitoneally within an interval of $15 \mathrm{~min}$ as described by Tahara et al. [15]. After 5 days, animals were assessed for successful induction of diabetes (fasting blood glucose $\geq 160 \mathrm{mg} / \mathrm{dl}$ ). The diabetic animals were divided into 10 groups of 10 animals with mean blood glucose of $232 \pm 2 \mathrm{mg} / \mathrm{dl}$ per group. The grouping was as described below:

Group 1: $5 \mathrm{ml} / \mathrm{kg}$ distilled water

Group 2: $0.02 \mathrm{mg} / \mathrm{kg}$ of estrogen

Group 3: $50 \mathrm{mg} / \mathrm{kg}$ extract $+0.02 \mathrm{mg} / \mathrm{kg}$ estradiol

Group 4: $150 \mathrm{mg} / \mathrm{kg}$ extract $+0.02 \mathrm{mg} / \mathrm{kg}$ estradiol

Group 5: $500 \mathrm{mg} / \mathrm{kg}$ extract $+0.02 \mathrm{mg} / \mathrm{kg}$ estradiol

Group 6: $50 \mathrm{mg} / \mathrm{kg}$ extract

Group 7: $150 \mathrm{mg} / \mathrm{kg}$ extract

Group 8: 500 mg/kg extract

Group 9: $30 \mathrm{mg} / \mathrm{kg}$ pioglitazone

Group 10: 100 mg/kg metformin.

In each group, 5 animals were used to monitor effect of treatment on lipid metabolism while the other half was used to monitor effect of treatment on glycermic control. Treatment lasted for 4 weeks while the animals were still maintained on high fat diet.

\section{Effect of Treatment on Chronic Diabetes}

Blood samples were drawn from tail vain of the diabetes animals in all the groups for the determination of pre-treatment fasting blood glucose concentration using One Touch Glucometer (Lifeshield, Johnson \& Johnson, California). After 4 weeks treatment, blood samples were obtained again from the animals for the determination of post-treatment fasting blood glucose concentration.

\section{Effect of Treatment on Oral Glucose Tolerance Test (OGTT)}

Prior to the test, the animals were fasted overnight and fasting blood glucose determined. The mice were given $2 \mathrm{~g} / \mathrm{kg}$ oral glucose solution. At 15, 30, 45, 60, and $120 \mathrm{~min}$ after the administration of glucose, blood samples were collected by tail milking and the glucose concentration 
estimated. The Area under the curve (AUC) of the plot of blood glucose against time was used to determine the oral glucose tolerance.

\section{Effect on Lipid Parameters}

Lipid parameters (total cholesterol, triglyceride, LDL-Cholesterol, and HDL-Cholesterol) were assayed using standard serum lipid assay kits (Randox). The procedure was followed as prescribed by the manufacturer.

\section{Statistical Analyses}

Statistical analyses was done using SPSS software (version 18). The data obtained was expressed as mean \pm SEM, analysed by KruskalWallis ANOVA test. The differences between various groups were determined by multiple comparisons of mean ranks for all groups. In all cases, a probability error of less than 0.05 was selected as the criterion for statistical significance.

\section{Result}

\section{Yield and Phytochemical Content}

The concentration extract weighed $10.4 \mathrm{~g}$ and the yield was calculated to be $5.2 \%$. Qualitative phytochemical analysis showed positive test for all the phytocompounds tested. Further quantitative analysis showed that terpenoids, saponins, flavonoids and tannins were $30.8,11.8,8.6$ and $6.9 \%$ respectively.

\section{Acute Toxicity Study}

Administration of the extract at $10-5000 \mathrm{mg} / \mathrm{kg}$ did not produce mortality or obvious signs of toxicity throughout the period of observation. Reduction in physical activities and eating were however observed after drug administration but normalized 30 minutes post administration.

\section{Effect of Supplementation of Low Dose Estradiol with $A$. paniculata on Chronic Diabetes}

Result of the pre-treatment blood glucose concentration showed no significant $(\mathrm{P}>0.05)$ differences across groups. However, after 4 weeks treatment, significant $(\mathrm{P}<0.05)$ reductions in blood glucose were recorded across the treatment groups when compared with vehicle control post-treatment value (Figure 1). Compared with individual group pre-treatment values, low doses of the extract $(50 \mathrm{mg} / \mathrm{kg})$ and estradiol $(0.02 \mathrm{mg} / \mathrm{kg})$ as monotherapy showed significantly $(\mathrm{P}<0.05)$ increased blood glucose concentration just like the vehicle
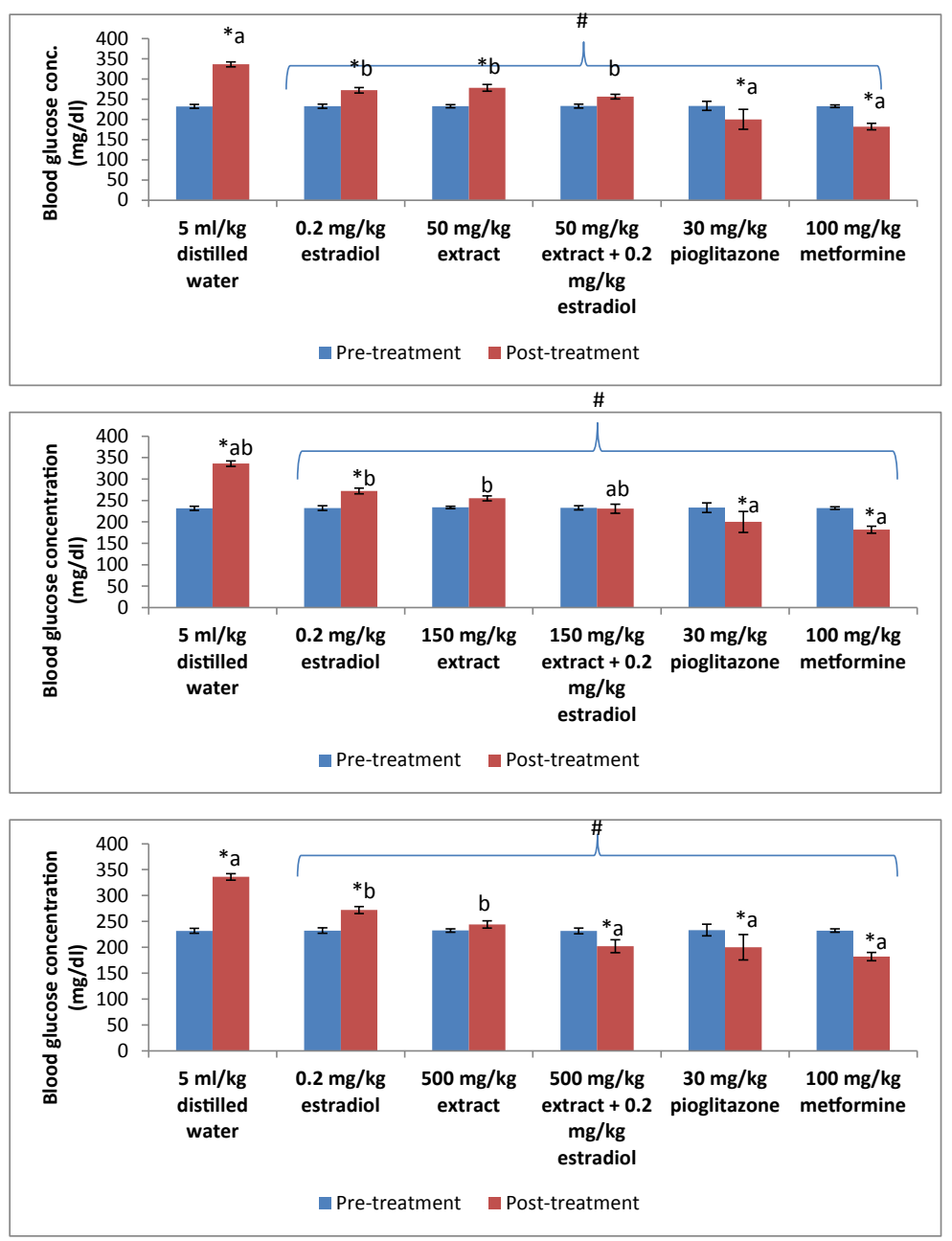

Figure 1: Pre-treatment and post-treatment blood glucose concentration.

${ }^{*} \mathrm{P}<0.05$ compared to pre-treatment; $\# \mathrm{P}<0.05$ compared to post-treatment $5 \mathrm{ml} / \mathrm{kg}$ distilled water (vehicle control); $\mathrm{a}=\mathrm{P}<0.05$ compared to extract/estradiol alone post-treatment; $\mathrm{b}=\mathrm{P}<0.05$ compared to pilocarpine/metformine post-treatment. 
control group. However, this significant increase was offset when these low doses were given as combination therapy. Combination of low dose estradiol with $500 \mathrm{mg} / \mathrm{kg}$ of the extract produced significant $(\mathrm{P}<0.05)$ reduction in blood glucose just like the reference standards pioglitazone $(30 \mathrm{mg} / \mathrm{kg})$ and metformine $(100 \mathrm{mg} / \mathrm{kg})$ when compared with their pre-treatment diabetic values. Also combination of low dose estradiol with 150 and $500 \mathrm{mg} / \mathrm{kg}$ of the extract showed significant $(\mathrm{P}<0.05)$ reduction in blood glucose when compared to their individual monotherapeutic effects.

\section{Effect of the Supplementation of Low Dose Estrogen with $A$. paniculata on Oral Glucose Tolerance}

The plasma glucose levels of the diabetic animals in each group peaked at 15 minutes post oral glucose load (Figure 2). However, animals treated with the extract and estradiol either alone or in combination produced lower blood glucose peak level in comparison to the vehicle control group ( $5 \mathrm{ml} / \mathrm{kg}$ distilled water). Oral glucose tolerance of the treated animals showed significant $(\mathrm{P}<0.05)$ improvement when compared to the vehicle control group (Figure 3). Co-administration of the extract with estradiol at all doses of the extract produced significant $(\mathrm{P}<0.05)$ improvement in oral glucose tolerance as depicted by smaller AUC when compared to either the extract or estradiol alone. The combination effect of the extract was dose dependent and at 150 and $500 \mathrm{mg} / \mathrm{kg}$ produced better oral glucose tolerant effect than low dose estradiol $(0.02 \mathrm{mg} / \mathrm{kg})$. However, the combination of the least dose $(50 \mathrm{mg} / \mathrm{kg})$ of the extract with estradiol produced similar effect as the highest dose of the extract (500 $\mathrm{mg} / \mathrm{kg}$ ). Combination effect of $150 \mathrm{mg} / \mathrm{kg}$ extract and estradiol was similar to the reference standard pioglitazone $(30 \mathrm{mg} / \mathrm{kg})$ as depicted by non-significant difference $(\mathrm{P}>0.05)$ in their AUC while at $500 \mathrm{mg} /$ $\mathrm{kg}$ of the extract, the combination effect was significantly $(\mathrm{P}<0.05)$ better than pioglitazone.

\section{Effect of the Supplementation of Low Dose Estrogen with $A$. paniculata on Lipid Profile}

From Figure 4, it was evident that low dose estradiol was unable to significantly improve diabesity associated lipid profile abnormalities. Similarly, low dose of $A$. paniculata extract $(50 \mathrm{mg} / \mathrm{kg})$ among other lipid parameters showed significant $(\mathrm{P}<0.05)$ reduction only in serum triglyceride (TG). Combination of both low doses of the extract and estradiol showed significant $(\mathrm{P}<0.05)$ reduction in serum TG and LDL-cholesterol as well as significant $(\mathrm{P}<0.05)$ increase in HDL compared to vehicle control group. Compared with low dose estradiol, combinations with the extract at 150 and $500 \mathrm{mg} /$ $\mathrm{kg}$ produced significant $(\mathrm{P}<0.05)$ reduction in serum TG, LDL and increased HDL while combination with $50 \mathrm{mg} / \mathrm{kg}$ of the extract only showed significant $(\mathrm{P}<0.05)$ difference on serum TG and LDL. Compared with the extract monotherapy, combination of estradiol

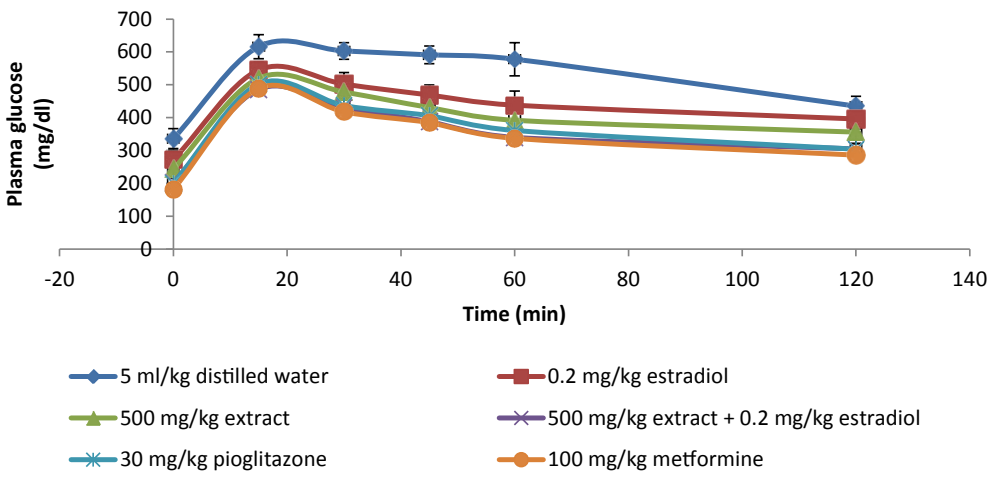

Figure 2: Plasma glucose concentration curve for $2 \mathrm{~h}$ oral glucose tolerance test.

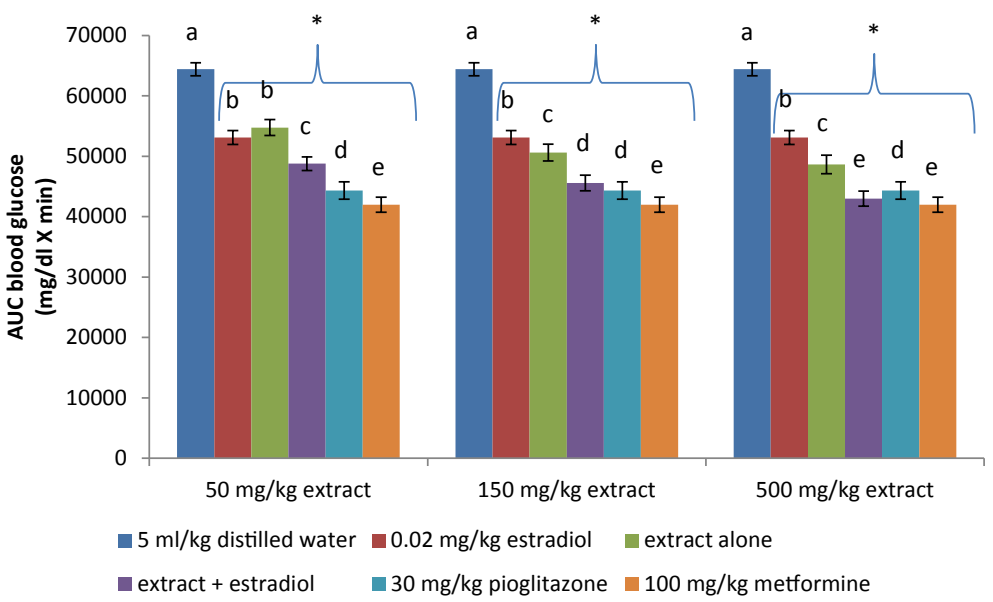

Figure 3: Area under the curve of oral glucose tolerant test.

${ }^{*} \mathrm{P}<0.05$ compared to $5 \mathrm{ml} / \mathrm{kg}$ distilled water (vehicle control); the alphabets a - e represents improved glucose tolerance in increasing order. Bars with different alphabets in each category indicates significant $(\mathrm{P}<0.05)$ difference. 


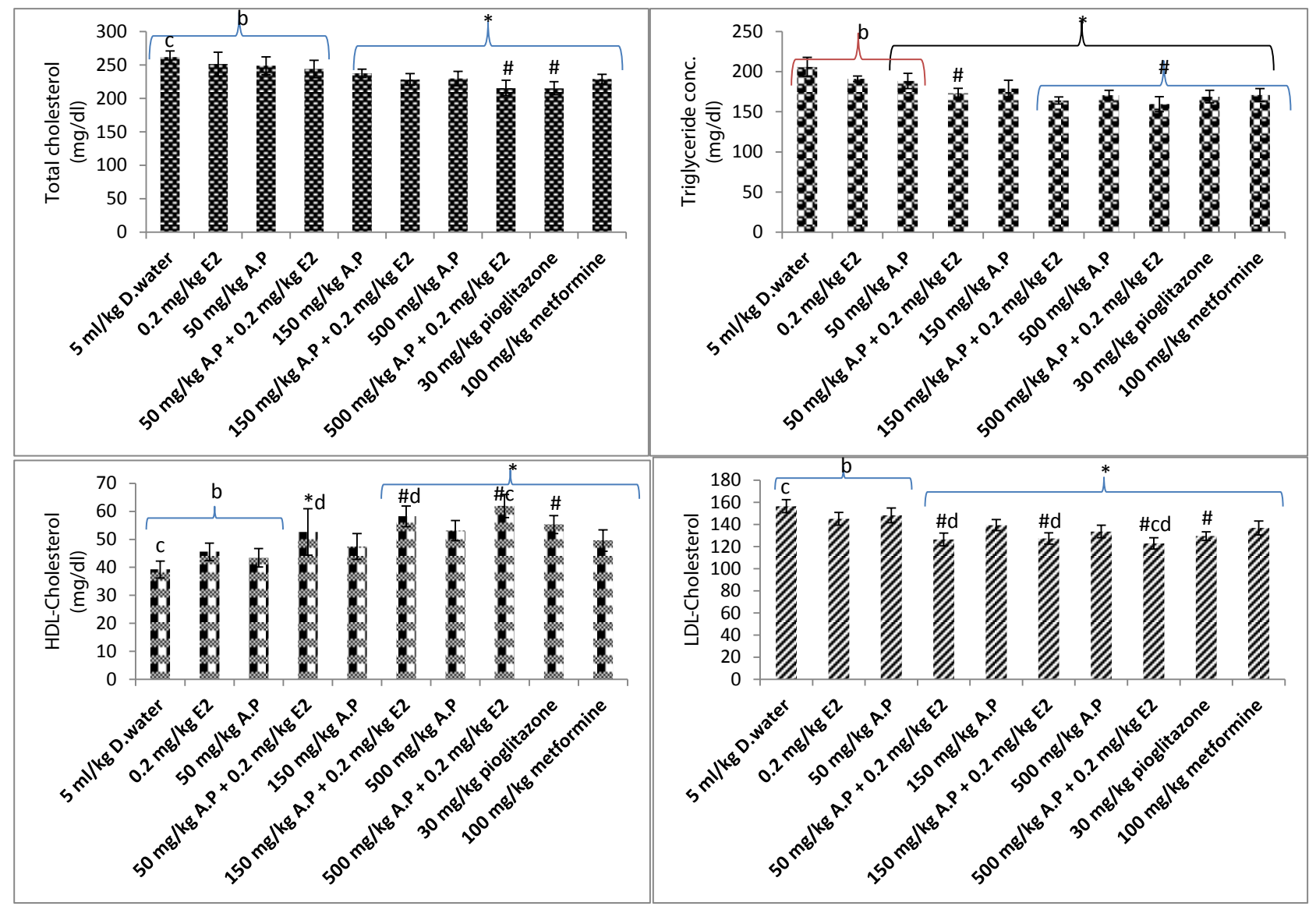

Figure 4: Effect of treatment on lipid profile.

with the extract at all the tested doses showed improvement in lipid profile with significant $(\mathrm{P}<0.05)$ reduction and increase recorded for LDL and HDL respectively. Combination of estradiol with the extract at $50 \mathrm{mg} / \mathrm{kg}$ produced similar effect on TG, LDL and HDL when compared to the reference standard pioglitazone $(30 \mathrm{mg} / \mathrm{kg})$. The monotherapeutic effects of low doses of the extract $(50 \mathrm{mg} / \mathrm{kg})$ and estradiol $(0.2 \mathrm{mg} / \mathrm{kg})$ on TG, LDL and HDL are significantly $(\mathrm{P}<0.05)$ lower than the reference standard pioglitazone. However, similar effects like pioglitazone were recorded on these lipid parameters when both treatments were given as combination therapy. Combination of low dose estradiol with $500 \mathrm{mg} / \mathrm{kg}$ of the extract produced significant $(\mathrm{P}<0.05)$ reduction in LDL and increase in HDL when compared to the reference standard metformine $(100 \mathrm{mg} / \mathrm{kg})$.

\section{Discussion}

One promising but yet poorly explored aspects of the regulation of glucose and lipid homeostasis is the use of estrogen. There is increasing evidence both in humans and rodents linking estrogen to the maintenance of glucose and lipid homeostasis [16]. Estrogen deficiency clearly predisposes males to increased adiposity and metabolic dysregulation [17]. In apparent contrast, however, obesity in men has been associated with hyperestrogenemia, and further excessive estradiol exposure has been postulated to play an exacerbating role in the progression of obesity and attendant metabolic dysregulation [18]. This study was designed to investigate the effect of low-dose $17 \beta$-estradiol supplemented with Andrographis paniculata on glucose and lipid homeostasis in a type-2 diabesity mice model.

High-fat diet-fed/STZ-NAD induced type 2 diabetes rats are a well-documented model of obesity-induced diabetes used for the screening antidiabetic agents. STZ preferentially accumulates in the $\beta$-cells via GLUT2 glucose transporter and induces the DNA strand breakage in $\beta$-cells causing a decrease in endogenous insulin release [19]. Many studies have reported that a long-term high-fat diet leads to insulin resistance and hyperinsulinaemia [20,21]. Intraperitonial administration of nicotinamide provides partial protection of the beta cells from complete STZ induced chemical pancreatectomy [14]. In other words, the high-fat diet combined with STZ-NAD induced diabetic rats have the characteristics of later-stage T2DM including hyperglycaemia, moderate impairment of insulin secretion, abnormalities in lipid metabolism, destruction of islet cells and reduced glycogen synthesis [22].

Dyslipidemia is a common abnormality associated with HFD consumption. Accumulation of excess fatty acid from lipid metabolism in non-adipose tissues (liver, pancreas and muscle) is a predominat feature of metabolic diseases like obesity and diabetes [23]. Subsequent metabolism of these fatty acids leads to decreased insulin-stimulated glucose uptake in skeletal muscle, unsuppressed hepatic glucose production and altered glucose-stimulated insulin release from B-cells [24]. Hyperglycermia resulting from these dysregulations in addition 
to FFA combine to generate major oxidative stress in tissues, further aggravating insulin resistance and deficiency. Estrogen modulates lipid concentration in plasma by regulating lipogenesis in adepocytes and hepatocytes [25]. The reduction in LDL and cholesterol level by low dose estrogen administration was probably as a result of estrogen induced accelerated conversion of hepatic cholesterol to bile acids and increased expression of LDL receptors on cell surfaces, resulting in augmented clearance of cholesterol and LDL from the plasma [26]. Other documented beneficial roles of estrogen on lipid metabolism include increase in lipoprotein lipase expression, increased fat oxidation and the regulation of acetyl-CoA oxidase as well as uncoupling proteins (UCP2-UCP3), which enhances fatty acid uptake without lipid accumulation [6].

A paniculata has also hyperlipidemia-lowering effect profile. One of its active compounds - Andrographolide has been reported to reduce serum cholesterol, triglycerides and LDL-cholesterol in hypercholesterolaemic patients and high-fat diet animals [27-28]. The combined effects of estrogen and A. paniculata on the same lipid homeostatic targets and separately on different regulatory targets may account for the improved lipid lowering effect of low estrogen supplemented with $A$. paniculata compared to effects recorded when they were administered separately.

Among the series of indices for testing $\beta$-cell function and insulin sensitivity, oral glucose tolerance test (OGTT) has emerged as a simple method that provides a reasonable approximation of wholebody insulin sensitivity [29]. The index of insulin sensitivity obtained from the oral glucose tolerance test has also been documented to be applicable to advanced type-2 diabetes [30]. Based on these documented evidences, we chose OGTT as our index for estimating insulin secretion and insulin sensitivity.

E2 regulates insulin action directly via actions on insulin-sensitive tissues or indirectly by regulating factors like oxidative stress which contributes to insulin resistance. In skeletal muscles, E2 via ERa have positive effect on insulin signalling and GLUT4 expression [31]. E2 also suppresses oxidative stress via both non genomic and genomic actions, by activating pathways that prevent generation of reactive oxygen species and increasing efficient scavenging of ROS [32]. The enhanced tolerance to oral glucose load by low-dose estrogen administration may have resulted from estrogen-mediated increase in sensitivity of skeletal muscle to insulin-stimulated glucose uptake. This enhanced response can account for improvement of the diabetic state in the partially pancreatectomized animals since small amount of endogenously insulin are likely to be secreted by the pancreatic remnant. Although estrogen is not an insulin secretagogue, it has however been reported to induces pancreatic beta-cell proliferation which may represent additional mechanism of improved glucose tolerance in this diabesity model [33].

Phytocompounds of A. Paniculata has been found to induce the mRNA and protein levels of GLUT4 - increasing glucose uptake in a time- and dose-dependent manner [34]. They also increase insulin secretion, acting as insulin secretagogue, as well as preventing loss of $\beta$-cells and/or their dysfunction through inhibition of ROS production and cytokine-stimulated NF-KB activation which are part of the mechanisms through which HFD and STZ damage the $\beta$-cells [35]. Supplementing estradiol with $A$. paniculata may have contributed to increase in insulin secretion with complementary stimulation of more insulin-mediated glucose uptake.

\section{Conclusion}

Augmentation of low-dose estrogen with A. paniculata resulted in the improvement of glucose and lipid homeostasis in a type- 2 diabesity mice model compared to their individual effects. The lowdose estrogen augmentation is expected to reduce the side effects of estrogen monotherapy while at the same time exploiting its metabolic potentials in glucose and lipid homeostasis. A. paniculata augmentation with low-dose estrogen elicited a better control of glucose and lipid parameters associated with diabesity.

\section{References}

1. Servan PR (2013) Obesity and diabetes. Nutr Hosp 28(5): 138-143. [crossref]

2. Haslam D (2010) Obesity and diabetes: the links and common approaches. Prim Care Diabetes 4(2): 105-12. [crossref]

3. Tabish SA. Is Diabetes Becoming the Biggest Epidemic of the Twenty-first Century? Int J Health Sci (Qassim) 1(2): 5-8. [crossref]

4. Zambard SP, Tuli D, Mathur A, Ghalsasi SA, Chaudhary A, Deshpande SS, Gupta RC, Chauthaiwale V, Dutt C, et al. (2013) TRC210258, a novel TGR5-agonist, reduces glycaemic and dyslipidaemic cardiovascular risk in animal models of diabesity. Diabetes Metab Syndr Obes 7: 1-14. [crossref]

5. Gupte AA, Pownall HJ, Hamilton DJ (2015) Estrogen: an emerging regulator of insulin action and mitochondrial function. J Diab Res 7: 1-9. [crossref]

6. Lizcano F, Guzmán G (2014) Estrogen Deficiency and the Origin of Obesity during Menopause. Biomed Res Int 2014: 757461. [crossref]

7. Louet J-F, LeMay C, Mauvais-Jarvis F (2004) Antidiabetic actions of estrogen: insight from human and genetic mouse models. Curr Atheroscler Rep 6: 180-185. [crossref]

8. Rossouw JE, Anderson GL, Prentice RL, LaCroix AZ, Kooperberg C, Stefanick ML, et al. (2002) Risks and benefits of estrogen plus progestin in healthy postmenopausal women: principal results from the women's health initiative randomized controlled trial, J Am Med Ass 288(3): 321-333. [crossref]

9. Okhuarobo A, Falodun JE, Erharuyi O, Imieje V, Falodun A, Langer P (2014) Harnessing the medicinal properties of Andrographis paniculata for diseases and beyond: a review of its phytochemistry and pharmacology. Asian Pac J Trop Dis 4(3): 213-22. [crossref]

10. Lee MJ, Rao YK, Chen K, Lee YC, Chung YS, Tzeng YM (2010) Andrographolide and 14-deoxy-11,12-didehydroandrographolide from Andrographis paniculata attenuate high glucose-induced fibrosis and apoptosis in murine renal mesangeal cell lines. $J$ Ethnopharmacol 132: 497-505. [crossref]

11. Zhang XF, Tan BK (2000) Anti-diabetic property of ethanolic extract of Andrographis paniculata in streptozotocin-diabetic rats. Acta Pharmacol Sin 21(12): 1157-64. [crossref]

12. Odoh UE, Obi PE, Ezea CC, Anwuchaepe AU (2019) Phytochemical methods in plant analysis. Pascal communications, Nsukka, Enugu State. 46. [crossref]

13. Agyigra I, Ejiofor J, Magaji M (2017) Acute and subchronic toxicity evaluation of methanol stem-bark extract of Ximenia americana Linn (Olacaceae) in Wistar rats. Bulletin of Faculty of Pharmacy Cairo University, 55(2): 263-267.

14. Mbagwu IS, Akah PA, Ajaghaku DL (2020) Newbouldia laevis improved glucose and fat homeostasis in a type-2 diabesity mice model. J Ethnopharmacol 251: 112555. [crossref]

15. Tahara A, Mastuyama-Yokono A, Shibasaki M (2011) Effects of antidiabetic drugs in high-fat diet and streptozotoain-nicotinamide-indiced type 2 diabetic mice. Eur $J$ Pharmacol 655(1-3): 108-116. [crossref]

16. Mauvais-Jarvis F, Clegg DJ, Hevener AL (2013) The role of estrogens in control of energy balance and glucose homeostasis. Endocr Rev 34(3): 309-38. [crossref] 
17. Rubinow KB (2017) Estrogens and Body Weight Regulation in Men. Adv Exp Med Biol 1043: 285-313. [crossref]

18. Mauvais-Jarvis F (2017) Sex and gender factors affecting metabolic homeostasis, diabetes and obesity, vol 1043. Cham: Springer International Publishing; https://link. springer.com/book/10.1007/978-3-319-70178-3.

19. Lenzen $S$ (2008) The mechanisms of alloxan- and streptozotocin-induced diabetes. Diabetologia 51(2): 216-26. [crossref]

20. Chalkley SM, Hettiarachchi M, Chisholm DJ, Kraegen EW (2002) Long-term highfat feeding leads to severe insulin resistance but not diabetes in Wistar rats. Am J Physiol Endocrinol Metab 282(6):E1231-8. [crossref]

21. Feng X, Scott A, Wang Y, Wang L, Zhao Y, Doerner S, Satake M, Croniger CM, Wang $\mathrm{Z}$ (2014) PTPRT regulates high-fat diet-induced obesity and insulin resistance. PLoS One 20;9(6):e100783. [crossref]

22. Whitton PD, Hems DA (1975) Glycogen synthesis in the perfused liver of streptozotocin-diabetic rats. Biochem J 150: 153-165. [crossref]

23. Castro AVB, Kolka CM, Kim SP, Bergman RN (2014) Obesity, insulin resistance and comorbidities ? Mechanisms of association. Arq Bras Endocrinol 58( 6 ): 600-609. [crossref]

24. Honka MJ, Latva-Rasku A, Bucci M, Virtanen KA, Hannukainen JC, Kalliokoski KK, Nuutila P, et al. (2018) Insulin-stimulated glucose uptake in skeletal muscle, adipose tissue and liver: a positron emission tomography study. Eur J Endocrinol 178(5): 523531. [crossref]

25. Kim JH, Cho HT, Kim YJ (2014) The role of estrogen in adipose tissue metabolism: Insights into glucose homeostasis regulation. Endocr J 61: 1055-1067. [crossref]

26. Guetta V, Cannon RO (1996) Cardiovascular effects of estrogen and lipid-lowering therapies in postmenopausal women. Circulation 93(10): 1928-1937. [crossref]
27. Reyes B, Bautista N, Tanquilut N, Anunciado R, Leung A, Sanchez G, et al. (2006) Antidiabetic potentials of Momordica charantia and Andrographis paniculata and their effects on estrous cyclicity of alloxan-induced diabetic rats. J Ethnopharmacol 105: 196-200.

28. Nugroho AE, Lindawati NY, Herlyanti K, Widyastuti L, Pramono S (2013) Antidiabetic effect of a combination of andrographolide-enriched extract of Andrographis paniculata (Burm f.) Nees and asiaticoside-enriched extract of Centella asiatica L. in high fructose-fat fed rats. Indian J Exp Biol 51: 1101-1108. [crossref]

29. Matsuda M, DeFronzo RA (1999) Insulin sensitivity indices obtained from oral glucose tolerance testing: comparison with the euglycemic insulin clamp. Diabetes Care 22(9): 1462-70. doi: 10.2337/diacare.22.9.1462. PMID: 10480510. [crossref]

30. Kanauchi M (2002) A new index of insulin sensitivity obtained from the oral glucose tolerance test applicable to advanced type 2 diabetes. Diabetes Care 25(10): 18911892. [crossref]

31. Mancini A, Raimondo S, Persano M, Di Segni C, Cammarano M, Gadotti G, Silvestrini A, Pontecorvi A, Meucci E (2013) Estrogens as antioxidant modulators in human fertility. Int J Endocrinol 2013: 607939. [crossref]

32. Wu T, Xu J, Xu S, Wu L, Zhu Y, Li G, Ren Z (2017) 17ß-Estradiol Promotes Islet Cell Proliferation in a Partial Pancreatectomy Mouse Model. J Endocr Soc 5;1(7): 965-979. [crossref]

33. Yu B, Hung C, Chen W, Cheng J (2014) Antihyperglycemic effect of Andrographolide in streptozotocin-induced diabetic rats. Planta Med 69: 1075-1079. [crossref]

34. Li Y, Yan H, Zhang Z, Zhang G, Sun Y, Yu P, Wang Y, Xu L (2015) Andrographolide derivative AL-1 improves insulin resistance through down-regulation of NF- $\kappa B$ signalling pathway. Br J Pharmacol 172(12): 3151-8. [crossref]

35. Barros RP, Machado UF, Warner M, Gustafsson JA (2006) Muscle GLUT4 regulation by estrogen receptors ERbeta and ERalpha. Proc Natl Acad Sci U S A 103(5): 1605-8. [crossref]

\section{Citation:}

Mbagwu IS, Ugwu OC, Orji UH, Offiah RO, Oraekei DI, et al. (2020) Low-Dose 17 $\beta$-Estradiol Supplemented with Andrographis Paniculata Improved Glucose and Lipid Homeostasis in a Type-2 Diabesity Mice Model. Endocrinol Diabetes Metab J Volume 4(5): 1-7. 